\title{
BEING FAT
}

Women, Weight, and Feminist Activism in Canada 


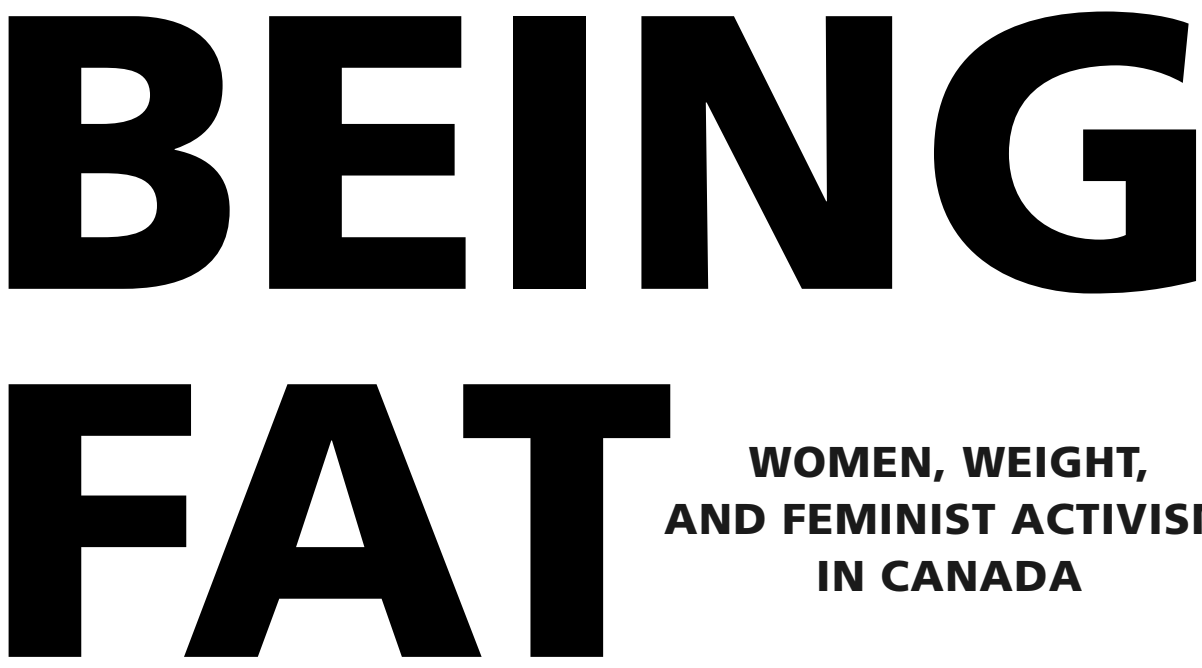

WOMEN, WEIGHT, AND FEMINIST ACTIVISM IN CANADA

JENNY ELLISON

UNIVERSITY OF TORONTO PRESS

Toronto Buffalo London 
(C) University of Toronto Press 2020

Toronto Buffalo London

utorontopress.com

Printed in Canada

ISBN 978-1-4875-0475-5 (cloth)

ISBN 978-1-4875-3082-2 (PDF)

ISBN 978-1-4875-2347-3 (paper)

ISBN 978-1-4875-3083-9 (EPUB)

\section{Library and Archives Canada Cataloguing in Publication}

Title: Being fat : women, weight, and feminist activism in Canada / Jenny Ellison.

Names: Ellison, Jenny, 1977- author.

Description: Includes bibliographical references and index.

Identifiers: Canadiana (print) 20190236604 | Canadiana (ebook) 20190236736 | ISBN 9781487523473 (paper) | ISBN 9781487504755 (cloth) | ISBN 9781487530822 (PDF) | ISBN 9781487530839 (EPUB)

Subjects: LCSH: Obesity in women - Social aspects - Canada. | LCSH:

Overweight women - Canada - Social conditions. | LCSH: Overweight women - Health and hygiene - Canada. | LCSH: Body weight - Social aspects - Canada. | LCSH: Fat-acceptance movement - Canada. | LCSH: Feminism - Canada.

Classification: LCC RC552.O25 .E45 2020 | DDC 362.1963/980082 - dc23

This book has been published with the help of a grant from the Federation for the Humanities and Social Sciences, through the Awards to Scholarly Publications Program, using funds provided by the Social Sciences and Humanities Research Council of Canada.

University of Toronto Press acknowledges the financial assistance to its publishing program of the Canada Council for the Arts and the Ontario Arts Council, an agency of the Government of Ontario.

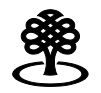

Canada Counci for the Arts

Funded by the Financé par le Government gouvernement of Canada

\section{Consell des Arts} du Canada

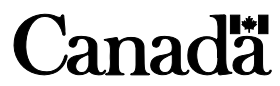

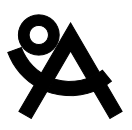

ONTARIO ARTS COUNCIL CONSEIL DES ARTS DE L'ONTARIO an Ontarlo government agency
un organlsme du gouvernement de rontarlo

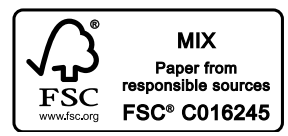




\section{Dies Irae}

On that day

Ripples will spread,

Fat will undulate,

Swell, sprawl,

Rampant,

Surging, insurgent.

No recanting then,

No mealy-mouthed forgiveness.

Our vengeance is curved,

Compact and keen.

Fat women

Are not few.

When we rise,

The earth will shake.

C.M. Donald, The Fat Woman Measures Up, 1986 
